Yale Agrarian Studies Series

James C. Scott, Series Editor 
“The Agrarian Studies Series at Yale University Press seeks to publish outstanding and original interdisciplinary work on agriculture and rural society - for any period, in any location. Works of daring that question existing paradigms and fill abstract categories with the lived-experience of rural people are especially encouraged."

James C. Scott, Series Editor

Brian Donahue, Reclaiming the Commons: Community Farms and Forests in a Nem England Tomn (1999)

James C. Scott, Seeing Like a State: How Certain Schemes to Improve the Human Condition Have Failed (1999)

Tamara L. Whited, Forests and Peasant Politics in Modern France (2000)

Peter Boomgaard, Frontiers of Fear: Tigers and People in the Malay World, I600-1950 (200I)

James C. Scott and Nina Bhatt, eds., Agrarian Studies: Synthetic Work at the Cutting Edge (200I)

Janet Vorwald Dohner, The Encyclopedia of Historic and Endangered Livestock and Poultry Breeds (2002)

Deborah Fitzgerald, Every Farm a Factory: The Industrial Ideal in American Agriculture (2003)

Stephen B. Brush, Farmers' Bounty: Locating Crop Diversity in the Contemporary World (2004)

Brian Donahue, The Great Meadom: Farmers and the Land in Colonial Concord (2004)

J. Gary Taylor and Patricia J. Scharlin, Smart Alliance: How a Global Corporation and Environmental Activists Transformed a Tarnished Brand (2004)

Raymond L. Bryant, Nongovernmental Organizations in Environmental Struggles: Politics and the Making of Moral Capital in the Philippines (2005)

Edward Friedman, Paul G. Pickowicz, and Mark Selden, Revolution, Resistance, and Reform in Village China (2005)

Michael Goldman, Imperial Nature: The World Bank and Struggles for Social Fustice in the Age of Globalization (2005)

Arvid Nelson, Cold War Ecology: Forests, Farms, and People in the East German Landscape, $1945^{-1989}$ (2005)

Steve Striffler, Chicken: The Dangerous Transformation of America's Favorite Food (2005)

Lynne Viola, V. P. Danilov, N. A. Ivnitskii, and Denis Kozlov, eds, The War Against the Peasantry, 1927-I930 (2005)

Parker Shipton, The Nature of Entrustment: Intimacy, Exchange, and the Sacred in Africa (2007)

For more information on the Yale Agrarian Studies Series, visit www.yalebooks.com. 


\section{The Nature of Entrustment}

Intimacy, Exchange, and the

Sacred in Africa

\section{Parker Shipton}

Yale University Press NEW HAVEN \& LONDON 
Copyright $(\mathcal{C} 2007$ by Parker Shipton.

All rights reserved.

This book may not be reproduced, in whole or in part, including illustrations, in any form (beyond that copying permitted by Sections 107 and 108 of the U.S. Copyright Law and except by reviewers for the public press), without written permission from the publishers.

Designed by James J. Johnson and set in Ehrhardt Roman by Tseng Information Systems, Inc. Printed in the United States of America by Sheridan Books.

Library of Congress Cataloging-in-Publication Data

Shipton, Parker MacDonald.

The nature of entrustment : intimacy, exchange, and the sacred in Africa / Parker Shipton.

p. cm. - (Yale agrarian studies series)

Includes bibliographical references and index.

ISBN: 978-0-300-I I6oI-4 (cloth : alk. paper)

I. Economic anthropology-Africa-Great Lakes Region. 2. Ceremonial exchange-Africa-Great Lakes Region. 3. Luo (Kenyan and Tanzanian people)-Finance. 4. Luo (Kenyan and Tanzanian people)-Commerce. 5. Luo (Kenyan and Tanzanian people)-Economic conditions. 6. Great Lakes Region (Africa) - Economic conditions. 7. Great Lakes Region (African) - Social life and customs.

I. Title

GN645.5515 2007

$306.3096-\mathrm{dc} 22$

2006033475

A catalogue record for this book is available from the British Library.

The paper in this book meets the guidelines for permanence and durability of the Committee on Production Guidelines for Book Longevity of the Council on Library Resources.

$\begin{array}{llllllllll}\text { I0 } & 9 & 8 & 7 & 6 & 5 & 4 & 3 & 2 & \text { I }\end{array}$ 
TO

James Morris Shipton

AND TO THE MEMORY OF

Mary Elizabeth Cornu Shipton 
